\title{
Seasonal variability of physico-chemical characteristics of the Haldia channel of Hooghly estuary, India
}

\author{
Y Sadhuram*, V V Sarma, T V Ramana Murthy and B Prabhakara Rao \\ National Institute of Oceanography, Regional Centre, Visakhapatnam, India. \\ *e-mail: sadhuram@darya.nio.org
}

\begin{abstract}
Physical and chemical characteristics of the Hooghly estuary during winter (December 1997January 1998), summer (May 1998) and post-monsoon (November 1998) seasons have been studied. Salinity varied spatially and temporally and seasonally during ebb and flood tide conditions. Water temperature showed a difference of $10^{\circ} \mathrm{C}$ in winter to summer. Temperature did not vary much vertically as it is a well-mixed estuary. Strong currents exceeding $100 \mathrm{~cm} \mathrm{~s}^{-1}$ were observed during peak ebb and flood tide conditions irrespective of the season. Longitudinal eddy diffusion coefficient $\left(K_{x}\right)$ was estimated as $757 \mathrm{~m} \mathrm{~s}^{-1}$ and $811 \mathrm{~m}^{2} \mathrm{~s}^{-1}$ during summer and post-monsoon seasons, respectively. The vertical eddy diffusion coefficient $\left(\varepsilon_{v}\right)$ was estimated as $0.0337 \mathrm{~m}^{2} \mathrm{~s}^{-1}$ during post-monsoon season. The salinity and current observations are compared with those obtained from models reported earlier. Values of $\mathrm{pH}$, Dissolved Oxygen and Biological Oxygen Demand are within the threshold limits of the estuarine environment. Nutrients show seasonal variation in the estuarine environment. High values $\left(160-2686 \mathrm{mg} \mathrm{l}^{-1}\right)$ of total suspended matter were noticed both at surface and bottom in the study region showing the impact of fresh water and sediment transportation.
\end{abstract}

\section{Introduction}

Hooghly river (figure 1) is a part of the Ganges and serves as a navigable waterway to Haldia and Calcutta ports. Tidal effect is noticeable in the river up to nearly $200 \mathrm{~km}$ from the mouth at Sagar Island. The salinity intrusion is confined to $70 \mathrm{~km}$ from the mouth even during the dry season. The tidal variation at the mouth is from $6.1 \mathrm{~m}$ at springs to $0.22 \mathrm{~m}$ at neaps. The fresh water discharge ranges from a peak value of $4250 \mathrm{~m}^{3} \mathrm{~s}^{-1}$ to almost zero in the dry season. The average values of fresh water discharge are $3000 \mathrm{~m}^{3} \mathrm{~s}^{-1}$ during SW monsoon season (June-September) and $1000 \mathrm{~m}^{3} \mathrm{~s}^{-1}$ during a dry season (November-May). Normally, the fresh water discharges are regulated from Farakka barrage to maintain water levels at Calcutta (Biswas 1985).

The estuary is shallow and the average depth is $6 \mathrm{~m}$. Because of shallow depths and intense tidal mixing, Hooghly estuary is a well-mixed type and vertically homogeneous throughout the year except for a short period during southwest monsoon season (June-September) in which the estuary is partially stratified due to high fresh water discharge (Gole and Vaidyaraman 1966). The large tidal variations, irregular coastal geometry, the presence of islands and the presence of navigational channels separated by shallow zones make the flow quite complicated.

Salinity and circulation in the Hooghly estuary have been reported from numerical models with very limited observations (Gole and Vaidyaraman 1969; McDowell and Prandle 1972; Chatterjee 1978, 1983; Sinha et al 1995, 1996 and 1999). Residual circulation and pollution transport are also studied by Sinha et al (1998). Recently, Sinha et al (2004) reported sediment transport in the estuary from a breadth-averaged model. Studies on chemical characteristics of the Hooghly estuary are very sparse. Qasim (2003) has reported various

Keywords. Physical characteristics; chemical characteristics; dispersion coefficient; currents; Hooghly estuary; Haldia channel. 


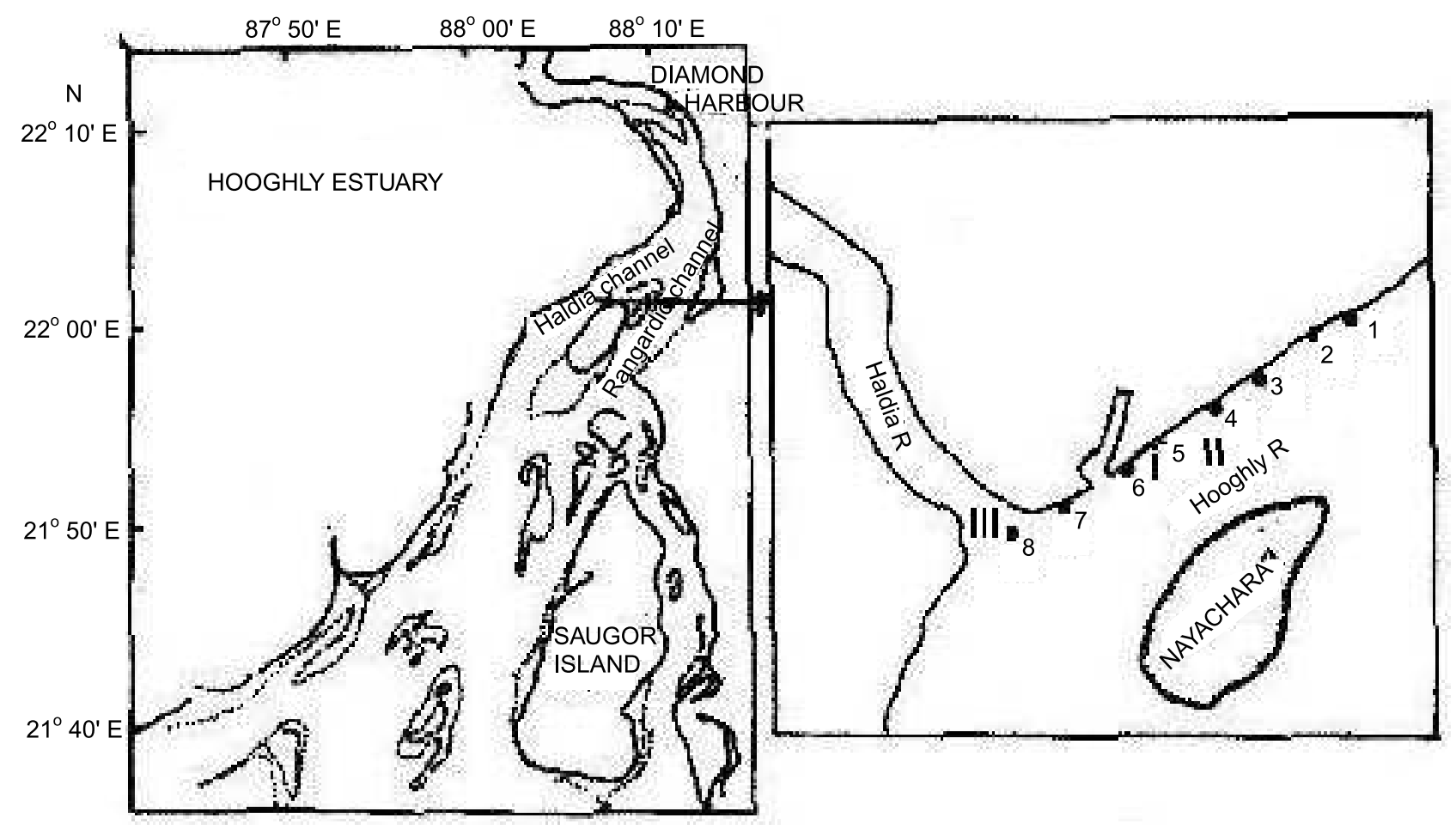

Figure 1. Study area and station locations.

aspects of the Hooghly estuary but the information on physical characteristics of the estuary is very sparse.

The main objective of this study is to present the physical and chemical characteristics of the Haldia channel of the Hooghly estuary under different seasons (winter, summer and post-monsoon) covering dry and low discharge conditions. The physical parameters (salinity and currents) which were collected using sophisticated equipment (details are given in the next section) are compared and discussed with those obtained from models.

\section{Data and methodology}

\subsection{Physical characteristics}

To study the physical characteristics, data on salinity, temperature and currents have been collected during winter (December 1997-January 1998), summer (May 1998) and post-monsoon (November 1998) seasons and the details are given in table 1. Due to heavy ships traffic and restrictions from the port authorities, our observations are restricted to Haldia channel (about $12 \mathrm{~km}$ stretch of the estuary).

\subsubsection{Salinity and temperature}

Salinity and temperature profiles at 8 stations (shown in figure 1) were collected using SBE 19
Seacat profiler (Make: Seabird Electronics, USA) under flood and ebb tidal conditions during the three seasons mentioned above. CTD data during winter could not be recorded, as there was a problem with the equipment.

\subsubsection{Currents}

Time series data on currents at $10 \mathrm{~min}$ interval were collected at stations 1-3 using RCM-7 current meters (Make; Aanderaa Instruments, Norway). The directional sensor at station 1 did not work during summer and the average direction observed during ebb and flood tide conditions at station 2 are used to compute $U$ component at station 1 during summer.

\subsubsection{Longitudinal dispersion coefficient $\left(K_{x}\right)$}

Hooghly estuary is shallow with an average water depth column of $6 \mathrm{~m}$. Because of this, Hooghly estuary is a well-mixed type and vertically homogenous. The large tidal variations, irregular coastal geometry, the presence of islands and the presence of navigational channels separated by shallow zones make the flow quite complicated. It is difficult to estimate the dispersion coefficient in a water body. To include all the processes, one should have a detailed knowledge of the estuary. Even though it was planned to collect all the data, it was not possible to do so due to shallow depths especially 
Table 1. Details of data collection.

\begin{tabular}{|c|c|c|c|}
\hline Season & Dates & Stations & Details of data collection \\
\hline \multirow{5}{*}{$\begin{array}{l}\text { Winter (27th December } \\
1997 \text { - 2nd January 1998) }\end{array}$} & $30 / 12 / 97-02 / 01 / 98$ & 1 & Time series data on currents \\
\hline & $27 / 12-29 / 12$ & 2 & $"$ \\
\hline & $31 / 12 / 97-02 / 01 / 98$ & 3 & $"$ \\
\hline & $27 / 12-30 / 12$ & Stations $1-8$ & $\begin{array}{l}\text { Surf. Met observations } \\
\text { water sampling }\end{array}$ \\
\hline & & Station 5 & $\begin{array}{l}\text { Two hourly water } \\
\text { sampling }\end{array}$ \\
\hline \multirow[t]{5}{*}{$\begin{array}{l}\text { Summer (11th-28th } \\
\text { May 1998) }\end{array}$} & $26 / 5-28 / 5$ & Stations $1-8$ & $\begin{array}{l}\text { Temp. and salinity profiles } \\
\text { under flood and ebb tidal } \\
\text { conditions }\end{array}$ \\
\hline & $18 / 5-23 / 5$ & 1 & Time series data on currents \\
\hline & $15 / 5-17 / 5$ & 2 & 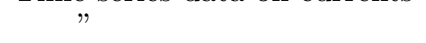 \\
\hline & $12 / 5-14 / 5$ & 3 & $"$ \\
\hline & $\begin{array}{l}\text { 11th, } 15 \text { th, } 26 \text { th, } \\
27 \text { th May }\end{array}$ & Stations 1-8 & $\begin{array}{l}\text { Surf. Met observations } \\
\text { water sampling }\end{array}$ \\
\hline \multirow[t]{9}{*}{$\begin{array}{l}\text { Post-monsoon (9th-23rd } \\
\text { November 1998) }\end{array}$} & $\begin{array}{l}\text { 9th, 12th, 16th, 17th, } \\
\text { 23rd November }\end{array}$ & Stations $1-8$ & $\begin{array}{l}\text { Temp. and salinity profiles } \\
\text { under flood and ebb tidal } \\
\text { conditions }\end{array}$ \\
\hline & $13 / 11$ & Station 2 & $\begin{array}{l}\text { Hourly data on temp. and } \\
\text { salinity during a tidal cycle }\end{array}$ \\
\hline & $13 / 11-14 / 11$ & Station 5 & Two hourly data on salinity \\
\hline & $10 / 11-11 / 11$ & Station 8 & $"$ \\
\hline & $13 / 11-17 / 11$ & Station 1 & $\begin{array}{l}\text { Time series data on currents, } \\
\text { temp. and salinity }\end{array}$ \\
\hline & $12 / 11-14 / 11$ & Station 2 & Time series data on currents \\
\hline & $10 / 11-12 / 11$ & Station 3 & $"$ \\
\hline & 12th, 16th-18th November & - & Surf. Met observations \\
\hline & & Stations $1-8$ & Sediment sampling \\
\hline
\end{tabular}

during low tide conditions. Further, the study area is a navigational channel and one should be very careful about ships traffic during data collection. CTD data collected at the stations 1-8, under several flood and ebb tide conditions, have been used to compute the average value of longitudinal dispersion coefficient $\left(K_{x}\right)$. The fresh water discharge assumed to be $3000 \mathrm{~m}^{3} \mathrm{~s}^{-1}$ for wet season and $1000 \mathrm{~m}^{3} \mathrm{~s}^{-1}$ for dry season (Sinha et al 1996). The cross sectional area in the upstream has been estimated from the depth contours.

A simple equation suggested earlier (Fischer et al 1979) had been used to compute $K_{x}$,

$$
K_{x}=\frac{\overline{U_{f}} \bar{S}}{\overline{\partial S} / \partial x},
$$

where $\overline{U_{f}}$ is the average speed of the fresh water into the study area which has been computed by using the fresh water discharge rate and the cross sectional area in the upstream. Average value of salinity at each station under different tidal cycles had been considered to compute the overall average of salinity $(\bar{S})$ in the study area. Similarly, average salinity gradient $\overline{\delta S} / \delta x$ has been worked out for the summer and post-monsoon seasons. The period from November to May is considered as the dry season, in which the fresh water discharge is expected to be low.

\subsubsection{Coefficient for vertical mixing $\left(\varepsilon_{v}\right)$}

Depending upon the prevailing environmental conditions and the topography of the water body, the vertical mixing highly varies from region to region. Normally the horizontal mixing will be several times more than the vertical mixing. Here, the coefficient for vertical mixing $\left(\varepsilon_{v}\right)$ has been estimated using the formula,

$$
\varepsilon_{v}=0.067 d U *
$$

where $d$ is the mean depth of the water column and $U *$ is the friction velocity. $U *$ is taken as $1 / 10$ of the $U_{t}$ as suggested by Fischer et al (1979). $\varepsilon_{v}$ is also computed from a different method (Schwind 1980). Time series data on salinity and speed fluctuation obtained from the RCM-7 current meter at a fixed location (which is close to station 2, deepest region) for a shorter duration, have been used to compute $\varepsilon_{v}$.

\subsubsection{Richardson number $\left(R_{i}\right)$}

The local Richardson number $\left(R_{i}\right)$ which indicates the stability of the water column is also important for mixing. The mixing of effluents in vertical also depends upon the stability of the water column. 
The formula suggested by Fischer et al (1979) has been used to compute $\left(R_{i}\right)$.

$$
R_{i}=\frac{\Delta \rho g d}{\rho u^{2}},
$$

where $\Delta \rho$ is the vertical density gradient in the water column and $\rho$ is the average density of the water column. $g$ is the acceleration due to gravity, $d$ is the depth of the water column, and $u$ is the mean tidal velocity. Taking into consideration all of the CTD data collected under ebb and flood tidal cycles, under three different seasons, the average value of $R_{i}$ has been computed.

\subsubsection{Meteorological observations}

Data on surface meteorological parameters, viz., wind speed, dry bulb and wet bulb temperatures, were collected at different locations, during the observational period. Wind speed was measured by portable anemometer. Dry bulb and wet bulb temperatures were measured by using psychomotor.

\subsection{Chemical characteristics}

Water samples were collected at surface and near bottom depths using Niskin bottles at the eight stations (figure 1) in the Hooghly estuary. The analysis for different chemical characteristics, viz., $\mathrm{pH}$, Dissolved Oxygen (DO), Biological Oxygen Demand (BOD), Nutrients, Total Suspended Matter (TSM) and Petroleum Hydrocarbons (PHC) have been estimated using standard methods (Grashoff 1976).

\section{Results and discussion}

\subsection{Physical characteristics}

\subsubsection{Salinity and temperature}

Salinity distribution in the study area under ebb and flood tide conditions during summer and postmonsoon seasons is presented in figure 2. During summer (dry period), salinity varied from 4.5$6.0 \mathrm{psu}$ and 7.0-13.0 psu under ebb and flood tide conditions, respectively. During post-monsoon season (low discharge) salinity drastically reduced to $0.2-1.2 \mathrm{psu}$ and 1.8-2.4 psu under ebb and flood tide conditions, respectively. Salinity at bottom was higher (2.6 psu) at stations 5 and 6 during the flood tide.

Salinity variations with tide at different stations are shown in figure 3. Salinity at station 5 during winter varied from $0.6-2.5 \mathrm{psu}$ and $2.7-10.0 \mathrm{psu}$ during post-monsoon season (figure $3 \mathrm{a}$ and $\mathrm{b}$ ) (please note that the curve in figure 3(a) is not continuous due to an erroneous value at $0300 \mathrm{hrs}$ ). At station 8 , salinity varied from $1.3-2.7 \mathrm{psu}$ during post-monsoon season (figure 3c). Salinity at station 2 during a tidal cycle on 13.11 .98 indicates that it varied from $0.6-2.2 \mathrm{psu}$. There is not much difference between the salinity at surface and bottom (not shown).

Time series data on temperature and salinity at station 1 during post-monsoon season have been presented in figure 4 . Water temperature (T) fluctuated between 27 and $28^{\circ} \mathrm{C}$ during postmonsoon season. Salinity variations with tide could be clearly seen in figure 4(b), which varied from $0.2-2.2 \mathrm{psu}$ and the range during a tidal cycle is about $2 \mathrm{psu}$.

\subsubsection{Depth averaged salinity, temperature and density}

The depth averaged salinity, temperature and density $\left(\mathrm{kg} \mathrm{m}^{-3}\right)$ under ebb and flood tides during the three seasons are shown in table 2. During winter salinity (estimated from titration method) varied from $1.12-5.44 \mathrm{psu}$ under flood tide conditions. During summer, salinity varied from 3.86$6.68 \mathrm{psu}$ and $7.23-13.3 \mathrm{psu}$ under ebb and flood tide conditions, respectively. There is a drastic fall in salinity from summer to post-monsoon season in which the salinity was only $0.17-1.11 \mathrm{psu}$ under ebb and 1.63-2.6 psu under flood tide and the range is only $1.0 \mathrm{psu}$ under both the cases. Water temperature is $20-21^{\circ} \mathrm{C}$ at stations $1-3$ during winter (not shown) and increased to $30-31^{\circ} \mathrm{C}$ during summer almost $10^{\circ} \mathrm{C}$ variation from winter to summer. During post-monsoon the temperature varied between 27 and $28^{\circ} \mathrm{C}$. Density of the water during summer was $999.5-1000.4 \mathrm{~kg} \mathrm{~m}^{-3}$ and $1000.0-1005.1 \mathrm{~kg} \mathrm{~m}^{-3}$ under ebb and flood tide conditions, respectively. It is interesting to note that the density values are lower than $1000 \mathrm{~kg} \mathrm{~m}^{-3}$ during post-monsoon season at all the stations under both ebb and flood tide conditions. It mostly varied from $997.1-998.4 \mathrm{~kg} \mathrm{~m}^{-3}$. It is interesting to note that these values are closer to the value of effective density ( $=993 \mathrm{~kg} \mathrm{~m}^{-3}$ for flood tide condition) which was introduced to measure water levels accurately in the highly turbid waters of Hooghly estuary (Joseph et al 1999). They noticed that the effective density is less than the bulk density (density of water-sediment mixture) and also less than that of the same water after removal of suspended sediments. The reduction in density of turbid natural waters could be due to the presence of air bubbles in water, dynamic uplift force acting on suspended sediment particles in the water column above the presence of a floc frame work. Suspended particulates experience loss of weight as a result of 

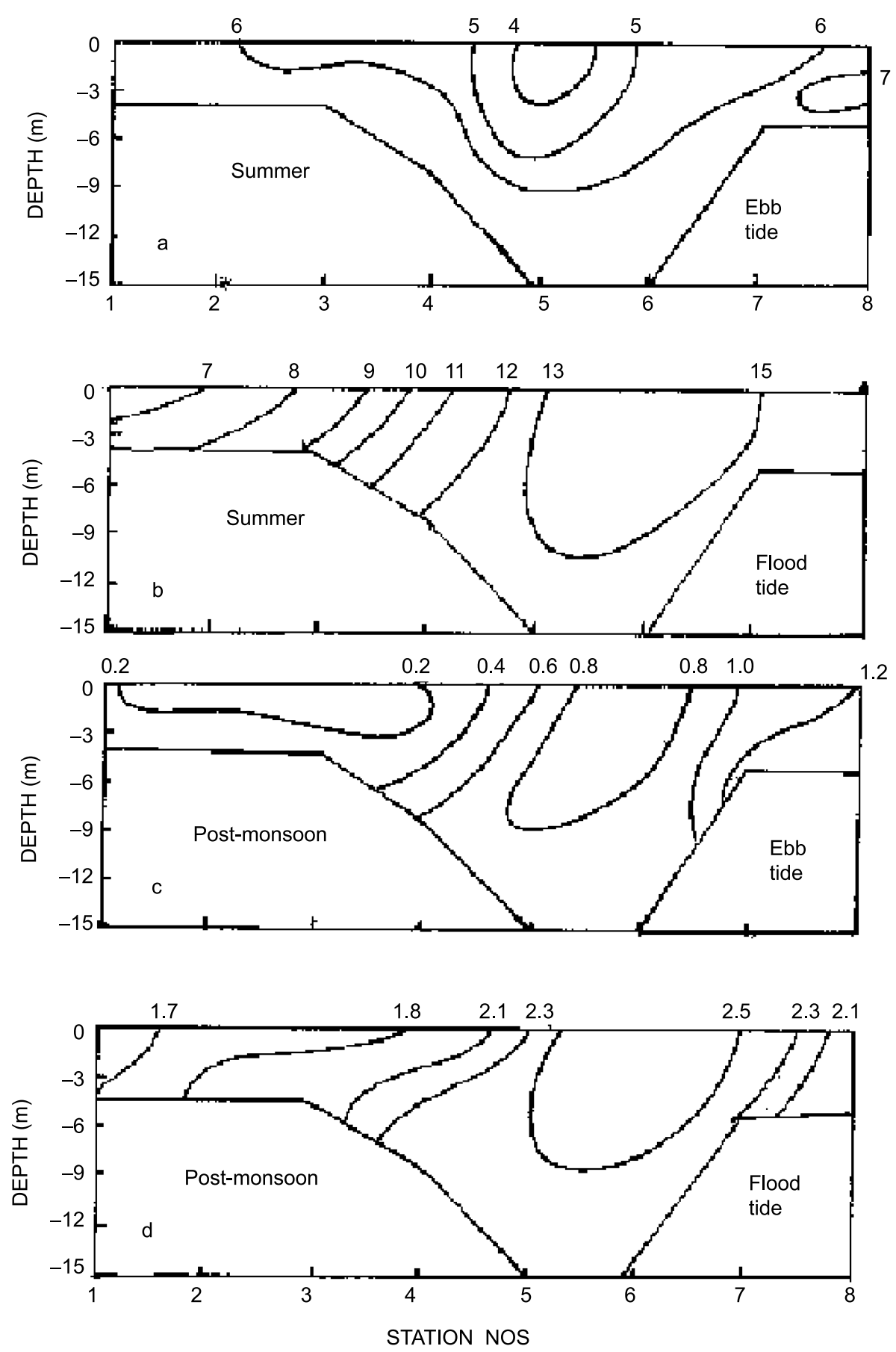

Figure 2. Salinity distribution during summer (a and b) and post-monsoon (c and $\mathbf{d}$ ) seasons under ebb and flood tide conditions.

uplift forces possibly caused by micro turbulence in the flowing water body and/or their rotation (Joseph et al 1997, 1999).

Earlier modeling studies (Sinha et al 1996, 1998, 1999) computed density $(\rho)$ by using the formula,

$$
\rho=\frac{\rho_{0}}{(1-\beta S)},
$$

where $\rho_{0}=$ reference density, $\beta=$ ratio of fractional change in density for unit change in salinity $\left(=6.5 \times 10^{-4}\right)$ and $S$ is the salinity. We have computed from the above equation and compared with the density values. It is found that the rms errors between the observed and computed density are 3.44 and 3.74 respectively for winter (dry conditions) and post-monsoon (low discharge) seasons. Using the density values from the 100 CTD profiles in the study area, the reference density $\left(\rho_{0}\right)$ from iteration process was estimated as 996.3 and $996.6 \mathrm{~kg} \mathrm{~m}^{-3}$ for dry and low discharge conditions respectively which gave very low rms error of 0.21 . 

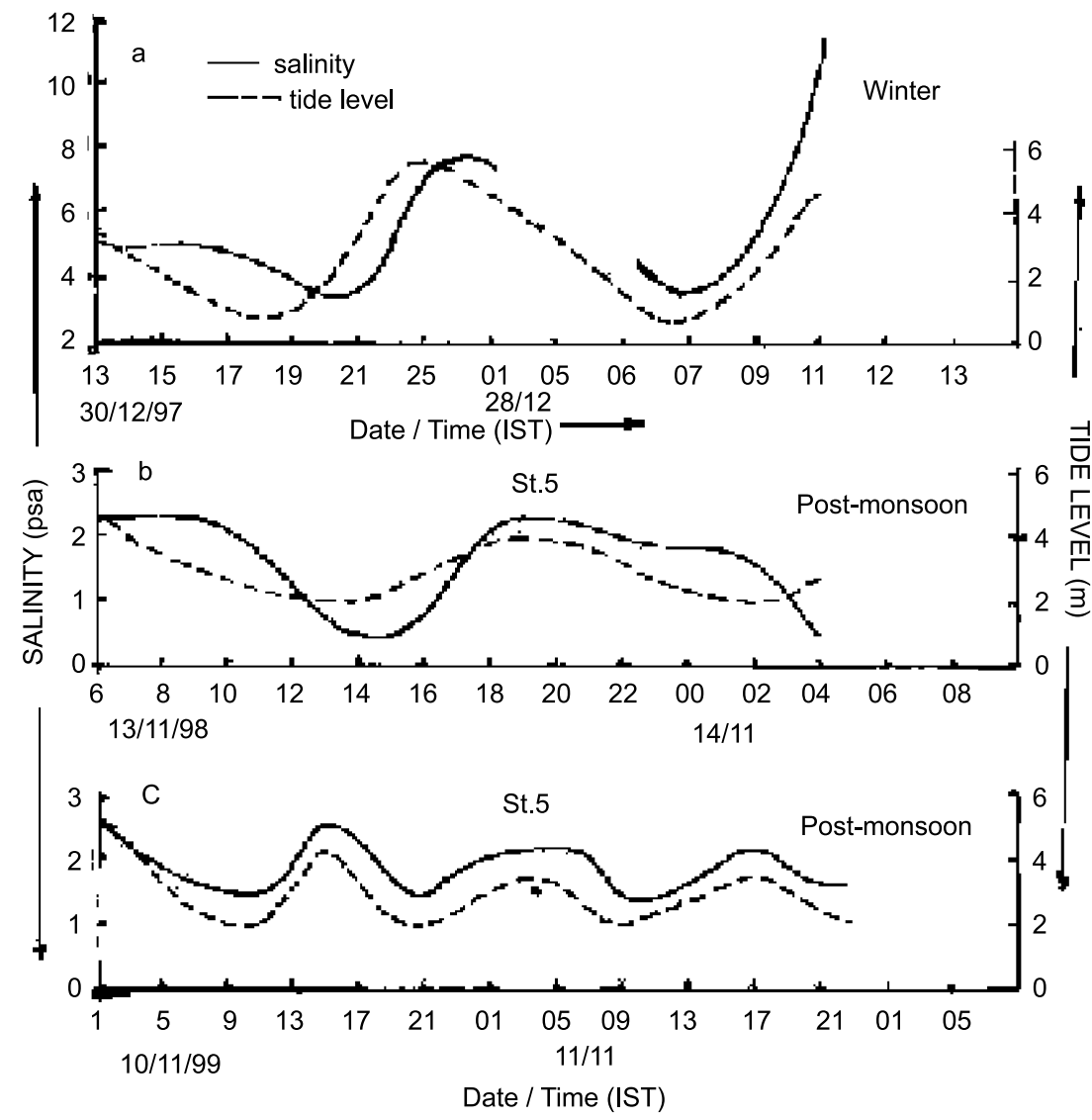

Figure 3. Tidal variation of salinity at station 5 (a and $\mathbf{b})$ and at station 8 (c) during winter and post-monsoon seasons.

By using the above reference density, the values of $\rho$ computed for any given depth are found to be closer. Hence, we suggest that modelers use $\rho_{0}$ as 996.3 and $996.6 \mathrm{~kg} \mathrm{~m}^{-3}$ respectively rather than $1000 \mathrm{~kg} \mathrm{~m}^{-3}$ for the dry and low discharge conditions, which may give better results.

\subsubsection{Currents}

Variation of $U$ (+ve indicates flood current and -ve indicates ebb current) at the three stations, viz., 1, 2 and 3 under the three seasons are depicted in figures 5-7. During winter, at station 1 , the maximum during flood and ebb tide was $0.8 \mathrm{~m} \mathrm{~s}^{-1}$ and $-1.4 \mathrm{~m} \mathrm{~s}^{-1}$ respectively. At station 2 which is located at a deeper channel, the currents are stronger compared with those at stations 1 and 2 . The maximum was $2.0 \mathrm{~m} \mathrm{~s}^{-1}$ during flood and $-1.4 \mathrm{~m} \mathrm{~s}^{-1}$ during ebb tide conditions. At station 3 , which is located at the Haldi river mouth, the strength of the current was less when compared with those at stations 1 and 2 . The maximum was $1.2 \mathrm{~m} \mathrm{~s}^{-1}$ and $-0.8 \mathrm{~m} \mathrm{~s}^{-1}$ respectively under flood and ebb tide conditions respectively (figure 5).

During summer, at station 1, the maximum during flood was $0.8 \mathrm{~m} \mathrm{~s}^{-1}$ and $-1.3 \mathrm{~m} \mathrm{~s}^{-1}$ under flood
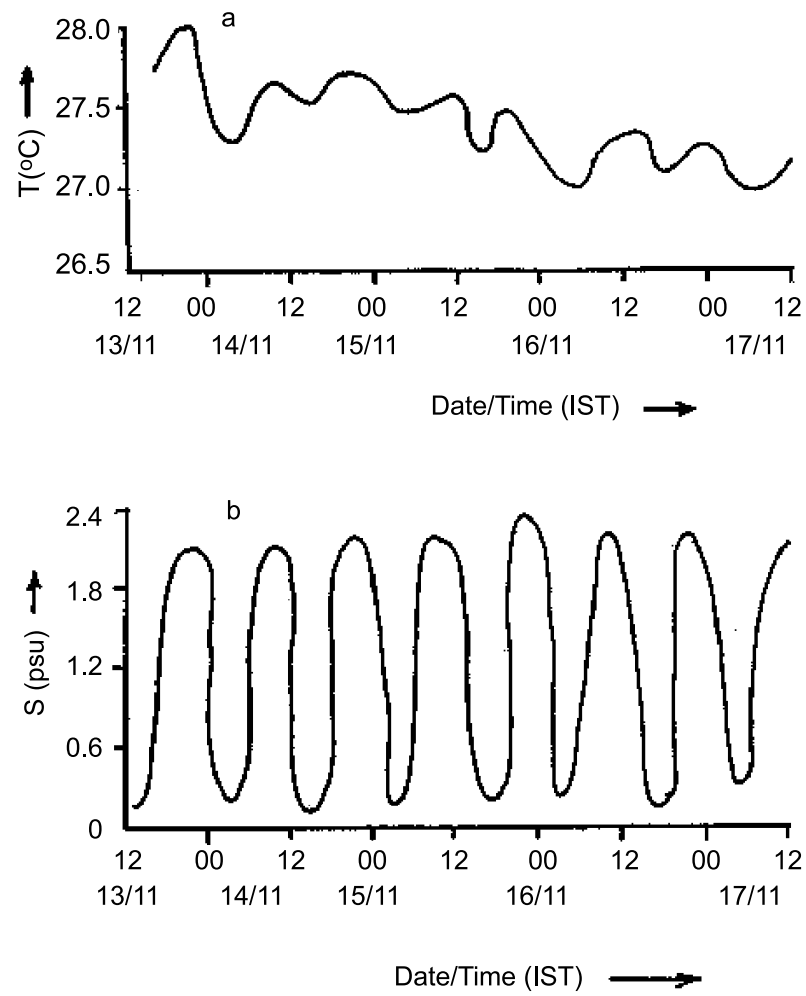

Figure 4. Temperature $\left({ }^{\circ} \mathrm{C}\right)$ and salinity (psu) variations at station 1 during post-monsoon season. 
Table 2. Depth averaged salinity (psu), Temperature $\left({ }^{\circ} \mathrm{C}\right)$ and Density $\left(\mathrm{kg} \mathrm{m}^{-3}\right)$ in the study area.

\begin{tabular}{cccccccccrc}
\hline & \multicolumn{4}{c}{ Salinity } & \multicolumn{4}{c}{ Temperature } & \multicolumn{3}{c}{ Density } \\
Stn. No. & & $\mathrm{W}$ & $\mathrm{S}$ & $\mathrm{P}$ & $\mathrm{W}$ & $\mathrm{S}$ & $\mathrm{P}$ & $\mathrm{W}$ & $\mathrm{S}$ & $\mathrm{P}$ \\
\hline \multirow{2}{*}{1} & $\mathrm{E}$ & - & 5.42 & 0.18 & - & 30.72 & 27.67 & - & 999.5 & 997.1 \\
& $\mathrm{~F}$ & 1.17 & 7.92 & 1.63 & - & 30.94 & 27.76 & - & 1001.5 & 997.5 \\
2 & $\mathrm{E}$ & - & 6.30 & 0.23 & - & 30.60 & 27.20 & - & 1000.2 & 997.2 \\
& $\mathrm{~F}$ & 1.54 & 7.23 & 1.84 & - & 30.97 & 27.10 & - & 1000.0 & 997.8 \\
3 & $\mathrm{E}$ & - & 6.08 & 0.20 & - & 30.69 & 27.56 & - & 1000.0 & 997.2 \\
& $\mathrm{~F}$ & 2.89 & 9.08 & 1.88 & - & 31.00 & 27.14 & - & 1002.0 & 997.9 \\
4 & $\mathrm{E}$ & - & 5.91 & 0.17 & - & 30.72 & 27.91 & - & 999.9 & 997.8 \\
& $\mathrm{~F}$ & 3.43 & 11.46 & 2.06 & - & 31.02 & 27.16 & - & 1003.8 & 998.0 \\
5 & $\mathrm{E}$ & - & 3.86 & 0.76 & - & 30.77 & 27.96 & - & 999.7 & 998.0 \\
& $\mathrm{~F}$ & 4.97 & 12.96 & 2.55 & - & 31.07 & 27.20 & - & 1004.9 & 998.4 \\
6 & $\mathrm{E}$ & - & 5.70 & 0.76 & - & 30.91 & 27.57 & - & 998.3 & 997.3 \\
& $\mathrm{~F}$ & 5.44 & 12.97 & 2.60 & - & 31.01 & 27.22 & - & 1004.9 & 998.4 \\
7 & $\mathrm{E}$ & - & 5.54 & 1.06 & - & 30.84 & 27.60 & - & 999.5 & 997.4 \\
& $\mathrm{~F}$ & 4.69 & 13.04 & 2.55 & - & 31.03 & 27.27 & - & 1005.0 & 998.3 \\
8 & $\mathrm{E}$ & - & 6.68 & 1.11 & - & 30.85 & 27.62 & - & 1000.4 & 997.5 \\
& $\mathrm{~F}$ & 4.06 & 13.30 & 2.03 & - & 31.08 & 27.82 & - & 1005.1 & 997.9 \\
\hline
\end{tabular}

$\mathbf{E}=$ Ebb tide $\mathbf{F}=$ flood tide $; \mathbf{W}=$ winter $; \mathbf{S}=$ summer $; \mathbf{P}=$ post-monsoon
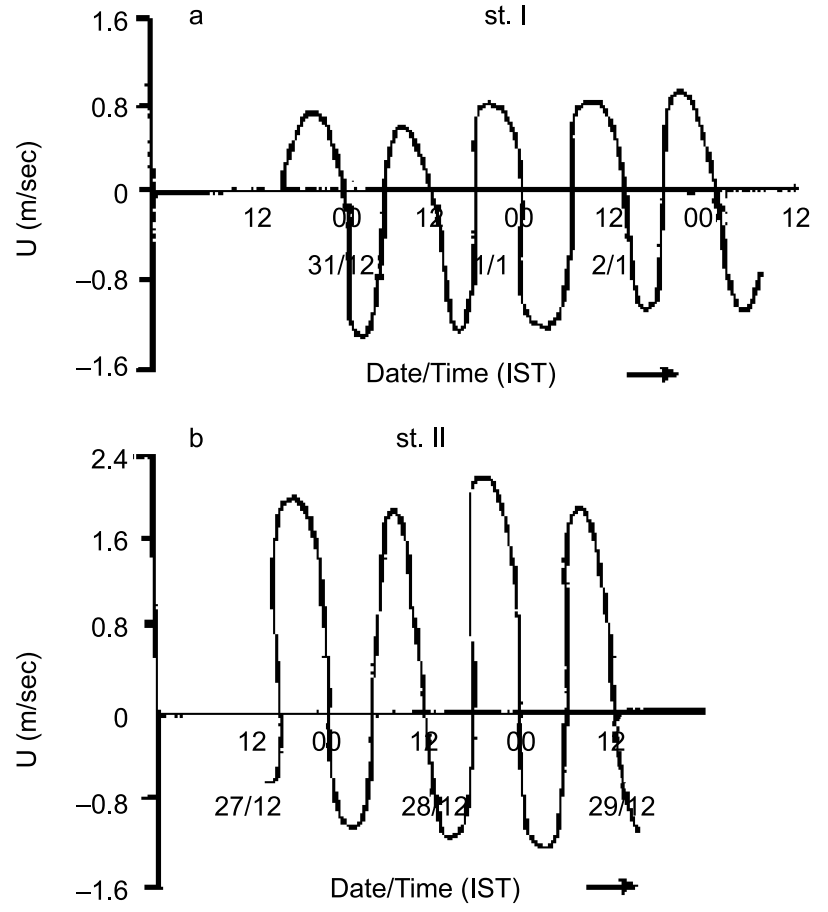

c st. III

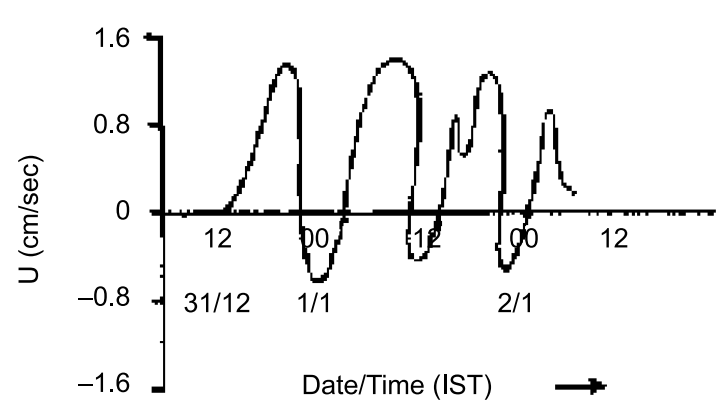

Figure 5. Currents at stations 1-3 during winter season (December 1997-January 1998). and ebb tide conditions respectively. At station 2, the currents are stronger compared with those at stations 1 and 3 as observed in winter. The maximum was 1.85 and $-1.5 \mathrm{~m} \mathrm{~s}^{-1}$ during flood and ebb tide conditions respectively. At station 3, the maximum during flood was 1.1 and $-0.8 \mathrm{~m} \mathrm{~s}^{-1}$ under ebb tide (figure 6).

During post-monsoon season, at station 1 , the maximum during flood was 0.8 and $-0.8 \mathrm{~m} \mathrm{~s}^{-1}$ and an almost equal magnitude under flood and ebb tide conditions. At station 2, the maximum was $1.0 \mathrm{~m} \mathrm{~s}^{-1}$ during flood tide and $-0.7 \mathrm{~m} \mathrm{~s}^{-1}$ under ebb tide. At station 3, currents during ebb are very low. The maximum during flood was $0.6 \mathrm{~m} \mathrm{~s}^{-1}$ while under ebb the maximum was only $-0.25 \mathrm{~m} \mathrm{~s}^{-1}$ (figure 7).

From the overall data, it is noticed that $U$ is almost double at station 2 during peak flood tide when compared with that at station 1 irrespective of the season even though they are located only $500 \mathrm{~m}$ (approx.) apart. This suggests that currents are highly variable laterally in this Haldia channel.

\subsubsection{Longitudinal dispersion coefficient $\left(K_{x}\right)$}

The average value of $K_{x}$ for the study area in summer was $757 \mathrm{~m}^{2} \mathrm{~s}^{-1}$ and post-monsoon $811 \mathrm{~m}^{2} \mathrm{~s}^{-1}$. This value appears to be reasonable for the study area. Sinha et al (1996) reported that the value of $K_{x}$ in Hooghly estuary varies between 500 and $1200 \mathrm{~m}^{2} \mathrm{~s}^{-1}$. For the sake of comparison, the values of $K_{x}$ for some estuaries are shown in table 3 .

Most of the values are approximately in the range of 160 to $800 \mathrm{~m}^{2} \mathrm{~s}^{-1}$, except Missouri in which the highest value of $1500 \mathrm{~m}^{2} \mathrm{~s}^{-1}$, was noticed. In Zuari estuary the values of $K_{x}$ were 

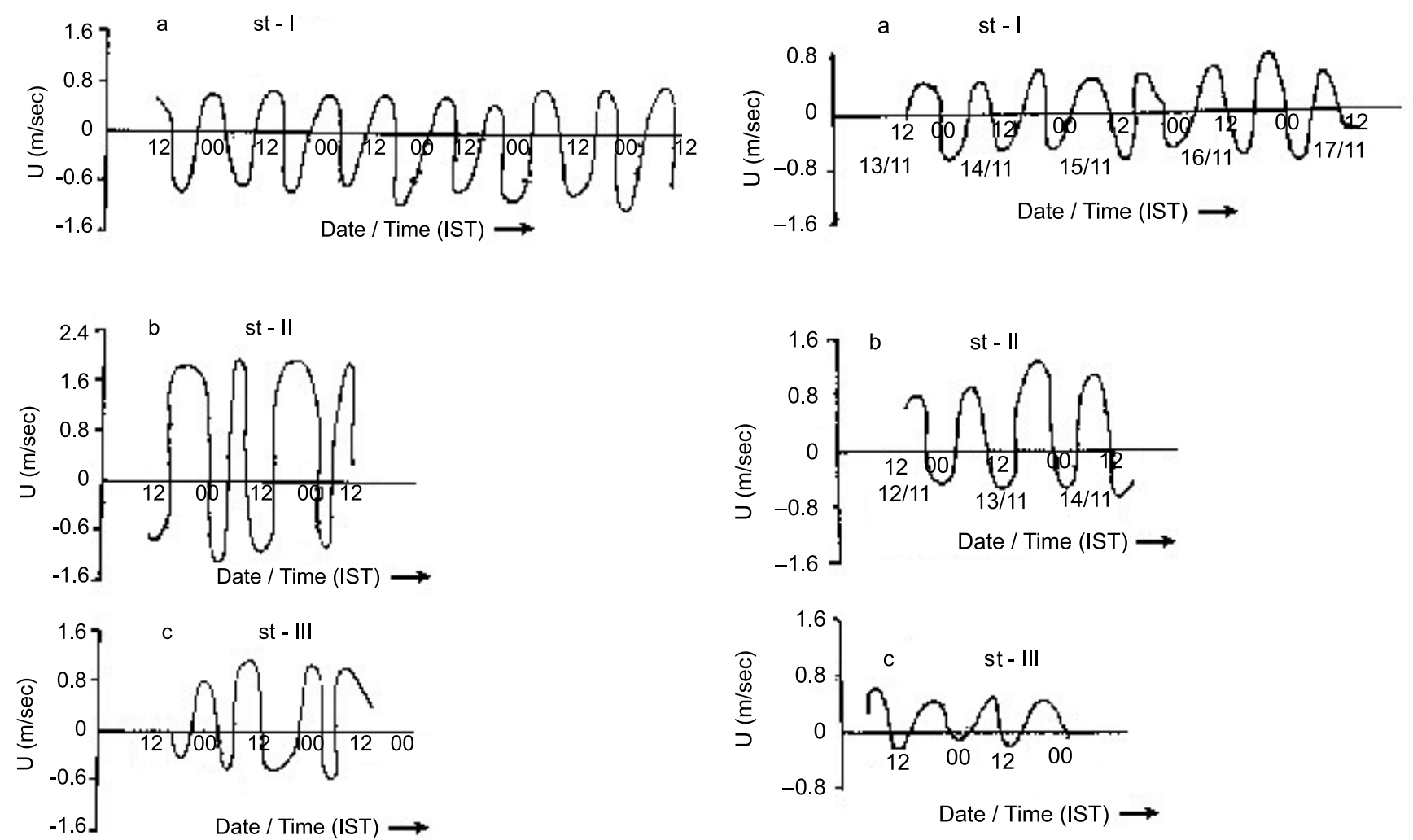

Figure 6. Same as figure 5, but for summer season (May 1998).

found to be 233 and $101 \mathrm{~m}^{2} / \mathrm{sec}$ (Shetye and Murthy 1987). Sinha et al (1996) reported a value of $K_{x}$ in general is $585 \mathrm{~m}^{2} \mathrm{~s}^{-1}$, but in some places they are as high as 1500 and as low as $150 \mathrm{~m}^{2} \mathrm{~s}^{-1}$, in the Hooghly estuary. In a model study, they have used an average value of $600 \mathrm{~m}^{2} \mathrm{~s}^{-1}$. From this it can be inferred that the present value based on systematic measurements of CTD and currents appears to be reasonable. For Godavari estuary, the value of $K_{x}$ for post-monsoon and pre-monsoon were reported $1510 \mathrm{~m}^{2} \mathrm{~s}^{-1}$ and $174 \mathrm{~m}^{2} \mathrm{~s}^{-1}$ respectively (Jyothi et al 2000).

\subsubsection{Vertical eddy diffusion coefficient $\left(\varepsilon_{v}\right)$}

The value of $\varepsilon_{v}$ is estimated at $0.028 \mathrm{~m}^{2} \mathrm{~s}^{-1}$ from the method suggested by Fischer et al (1979) while from a different approach (Schwind 1980) the value of $\varepsilon_{v}$ is estimated as $0.0337 \mathrm{~m}^{2} \mathrm{~s}^{-1}$. It is interesting to see there is a close agreement between the two values. The average value of $R_{i}$ is of the order of 0.1 , which indicates highly unstable conditions in the study area. This further supports the intensive vertical mixing.

\subsubsection{Comparison between the parameters observed and computed from models}

The observed currents at station 2 during winter and summer (figures 4 and 5) are comparable

Figure 7. Same as figure 6, but for post-monsoon season (November 1998).

Table 3. Longitudinal dispersion coefficients $\left(K_{x}\right)$ in estuaries.

\begin{tabular}{clc}
\hline S.No & \multicolumn{1}{c}{ Estuary } & $K_{x}\left(\mathrm{~m}^{2} \mathrm{~s}^{-1}\right)$ \\
\hline 1 & Hudson & 160 \\
2 & Delaware & $500-1500$ \\
3 & San Francisco Bay & 200 \\
4 & Thames & 338 \\
5 & Sabine river & 670 \\
6 & Yadkin river & 260 \\
7 & Hooghly estuary & 784 \\
8 & Missouri river & 1500 \\
\hline
\end{tabular}

with computed currents at station 2 (Haldia) at surface with schemes 1 and 2 . Salinity variations and magnitude observed at station 5 during winter season (figure $3 \mathrm{a}$ ) are comparable with the estimated salinity from scheme I at station 2. Salinity distribution during flood and ebb tide conditions (figure 2a and b) are comparable with the computed salinity distribution $(5-20 \mathrm{~km})$ from scheme I (figures 12-14: Sinha et al 1999). They have reported the maximum values of eddy diffusivity at deeper regions from schemes I and II as 38 and $45 \mathrm{~cm}^{2} \mathrm{~s}^{-1}$ respectively in the estuary. Our present value with the limited data collected at the same region is about $337 \mathrm{~cm}^{2} \mathrm{~s}^{-1}$, which is one order higher than the above value. However, this has to be confirmed with more data sets. The value of $K_{x}$ is $784 \mathrm{~m}^{2} \mathrm{~s}^{-1}$ which is very close to the value 
$750 \mathrm{~m}^{2} \mathrm{~s}^{-1}$ assumed in the model to study the pollution transport (Sinha et al 1998).

\subsubsection{Surface meteorological observations}

Table 4 shows the average values of surface meteorological parameters under the three seasons. Dur-

Table 4. Surface meteorological observations.

\begin{tabular}{lccc}
\hline \multicolumn{1}{c}{ Season } & $\begin{array}{c}\text { Dry bulb } \\
\text { temp. }\left({ }^{\circ} \mathrm{C}\right)\end{array}$ & $\begin{array}{c}\text { Wet bulb } \\
\text { temp. }\left({ }^{\circ} \mathrm{C}\right)\end{array}$ & $\begin{array}{c}\text { Wind speed } \\
\left(\mathrm{m} \mathrm{s}^{-1}\right)\end{array}$ \\
\hline Winter & 22.35 & 18.30 & 2.45 \\
Summer & 33.05 & 29.42 & 5.20 \\
Post-monsoon & 28.73 & 26.07 & 3.03 \\
\hline
\end{tabular}

ing winter, the average value of wind speed is $2.45 \mathrm{~m} / \mathrm{s}$. The average value of dry bulb and wet bulb temperatures are 22.35 and $18.3^{\circ} \mathrm{C}$. During summer, dry and wet bulb temperatures were $33.05^{\circ} \mathrm{C}$ and $29.42^{\circ} \mathrm{C}$ respectively. Average wind speed was $5.2 \mathrm{~m} / \mathrm{s}$. During post monsoon season, the dry bulb and wet bulb temperatures were $28.73^{\circ} \mathrm{C}$ and $26.07^{\circ} \mathrm{C}$ respectively. The average wind speed was $3.03 \mathrm{~m} / \mathrm{sec}$.

The high value of $K_{x}\left(784 \mathrm{~m}^{2} \mathrm{~s}^{-1}\right)$ indicates the possibility of strong mixing of pollutants in the estuary. Absence of vertical gradients in temperature and salinity at different locations, under flood and ebb tide conditions also support strong vertical mixing in the study area.
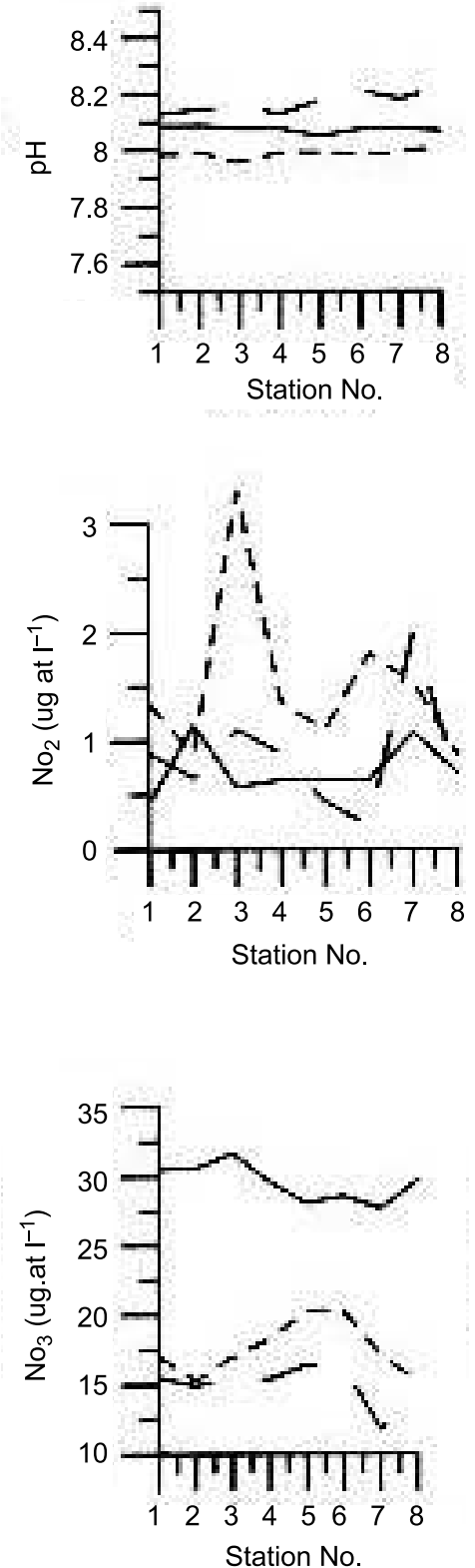
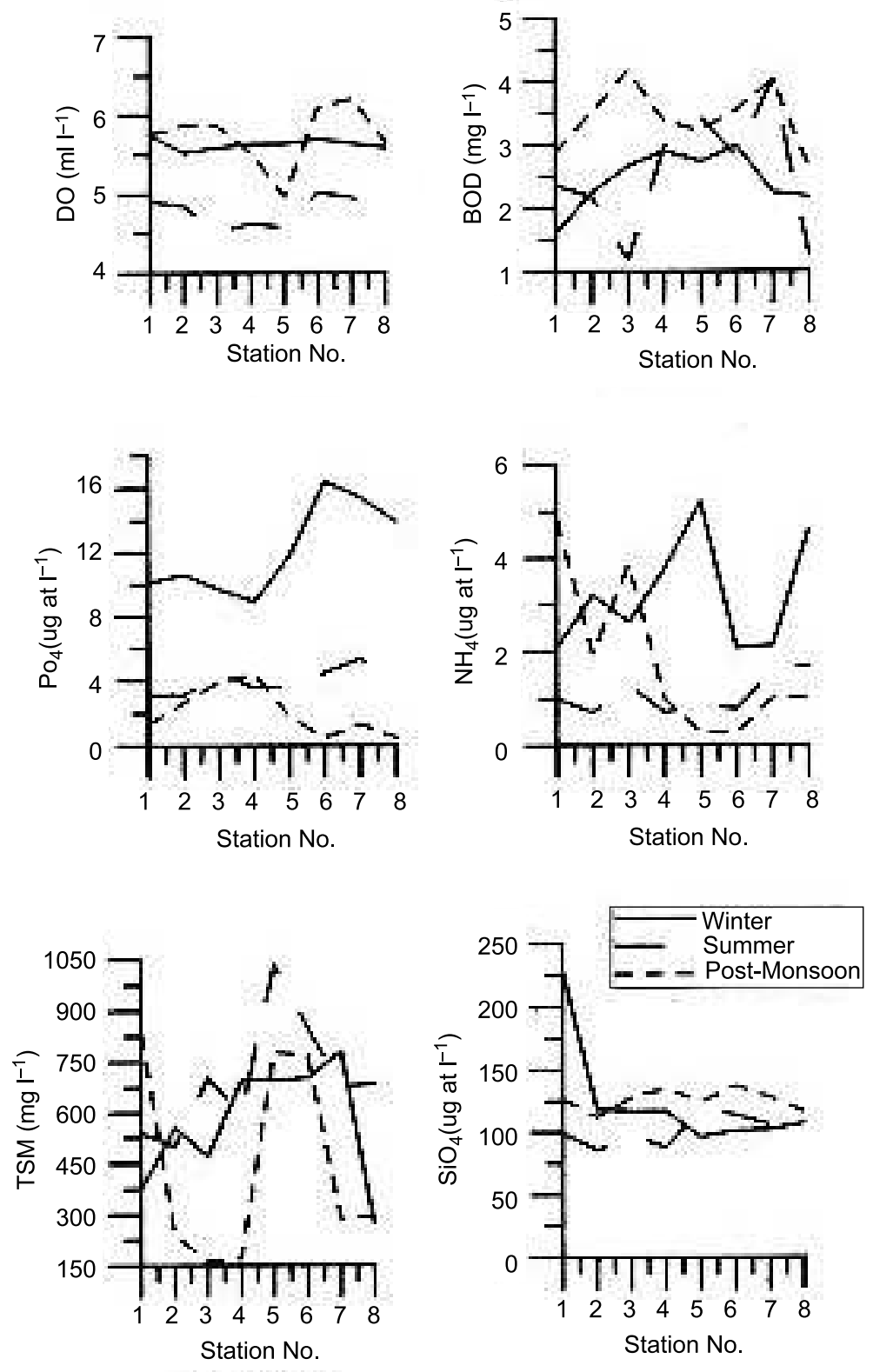

Figure 8. (a) Hydro chemical characteristics at surface in the Haldia channel, Hooghly estuary during winter, summer and post-monsoon seasons; (b) Same as figure 8(a) but at bottom. 

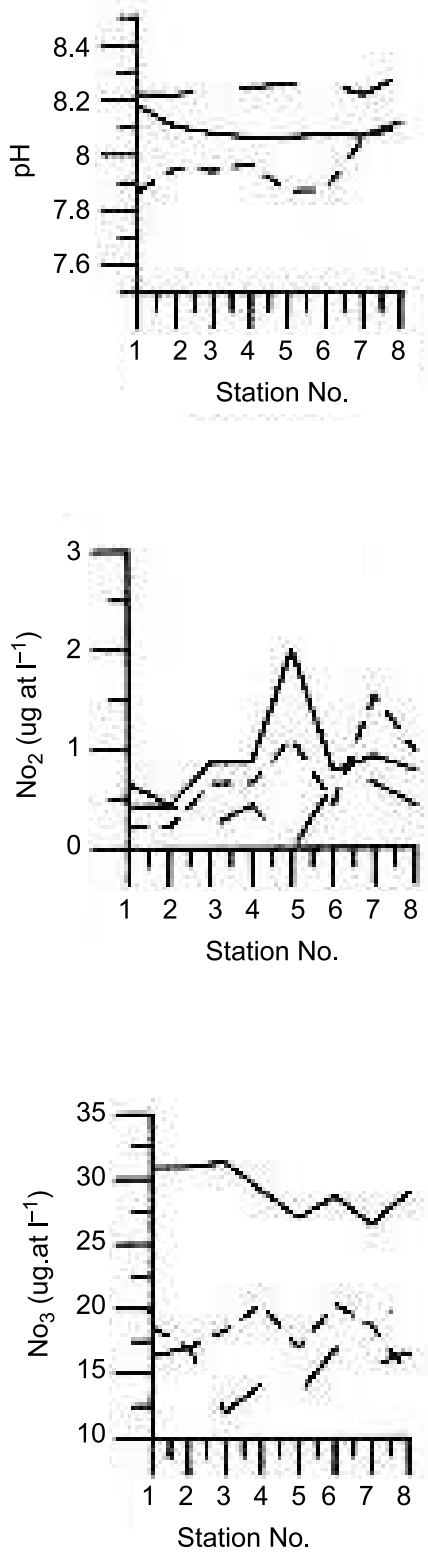
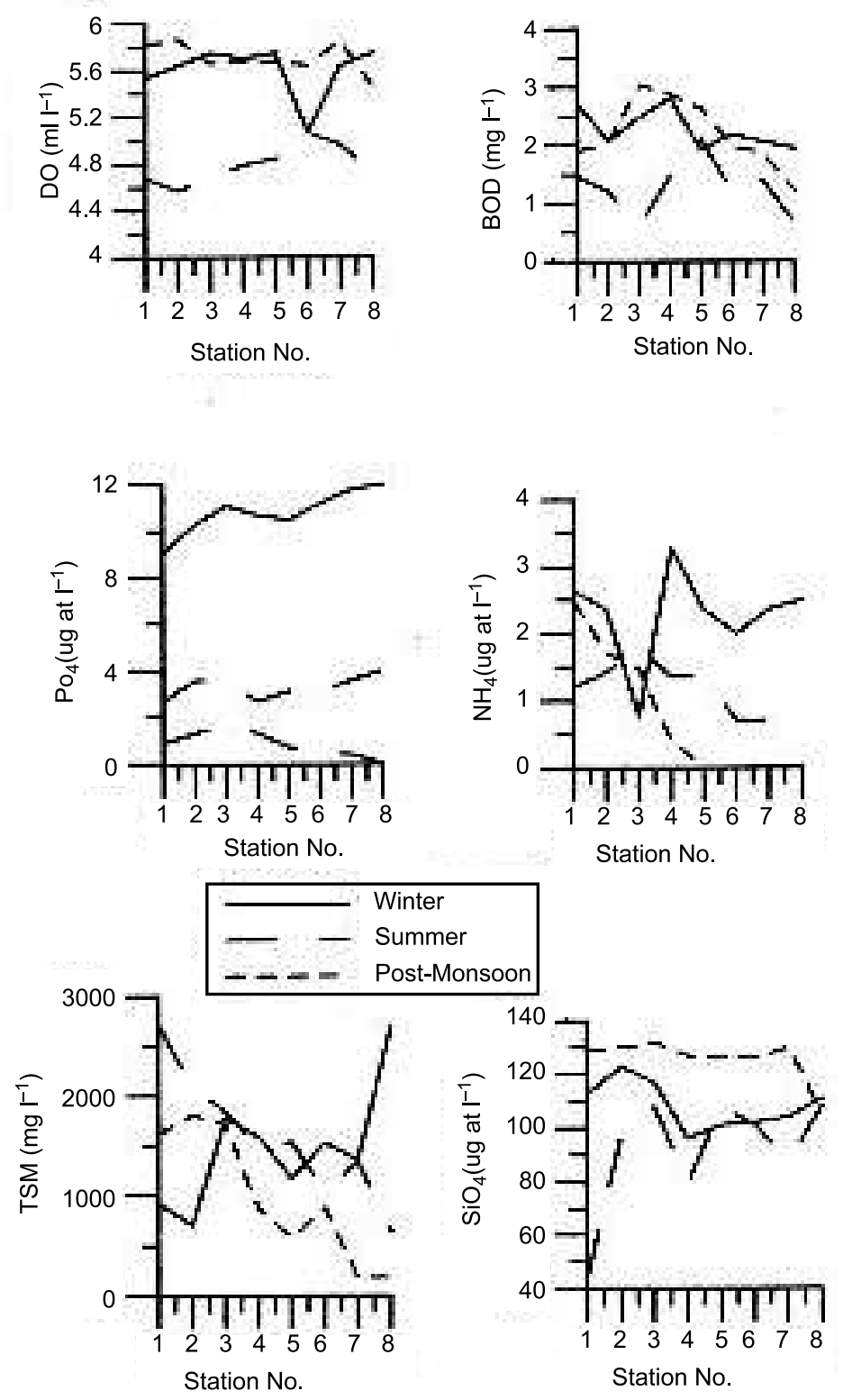

Figure 8(b). (Continued)

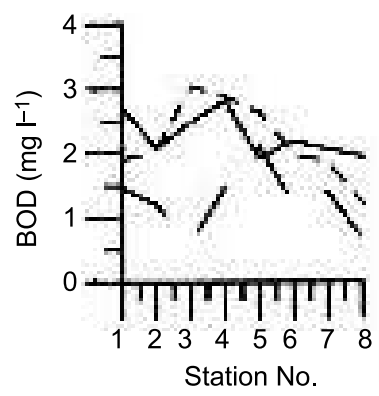

Based on the data, the computed parameters $K_{x}$ and $\varepsilon_{v}$, are found to be $784 \mathrm{~m}^{2} \mathrm{~s}^{-1}$ and $0.0337 \mathrm{~m}^{2} \mathrm{~s}^{-1}$ respectively. The value of $K_{x}$ is close to the value $750 \mathrm{~m}^{2} \mathrm{~s}^{-1}$ used in the modeling study by Sinha et al (1998).

\subsection{Chemical characteristics}

Variations in chemical characteristics during different seasons in the study area are depicted in figure 8.

$\mathrm{pH}$ varied between 8.05 and $8.18 ; 8.12$ and 8.28 and 7.87 and 8.09 during winter, summer and post-monsoon seasons, respectively in the study region. Vertical gradient in $\mathrm{pH}$ is almost negligible.

DO in surface and bottom waters did not vary much $\left(4.51-5.07 \mathrm{ml} \mathrm{l}^{-1}\right)$ during winter and summer $\left(5.07-5.75 \mathrm{ml} \mathrm{l}^{-1}\right)$ and small changes, however (4.97-6.21 $\mathrm{ml} \mathrm{l}^{-1}$ ) were recorded during post-monsoon season. This suggests well mixed conditions in the estuary. Relatively higher oxygen concentrations in winter and post-monsoon seasons showed the flow of freshwater wherein oxygen solubility is greater. It is apparent from the data that oxygen concentration was controlled by hydrographical parameters (temperature and salinity) in association with physical and biological processes in the estuarine environment.

$\mathrm{BOD}_{5}$ values ranged between 0.67 and $4.17 \mathrm{mg} \mathrm{l}^{-1}$ during winter; summer and postmonsoon seasons, are considered to be lower than the threshold limits $\left(<5.0 \mathrm{mg} \mathrm{l}^{-1}\right)$ and may not pose any threat to the aquatic environment. 


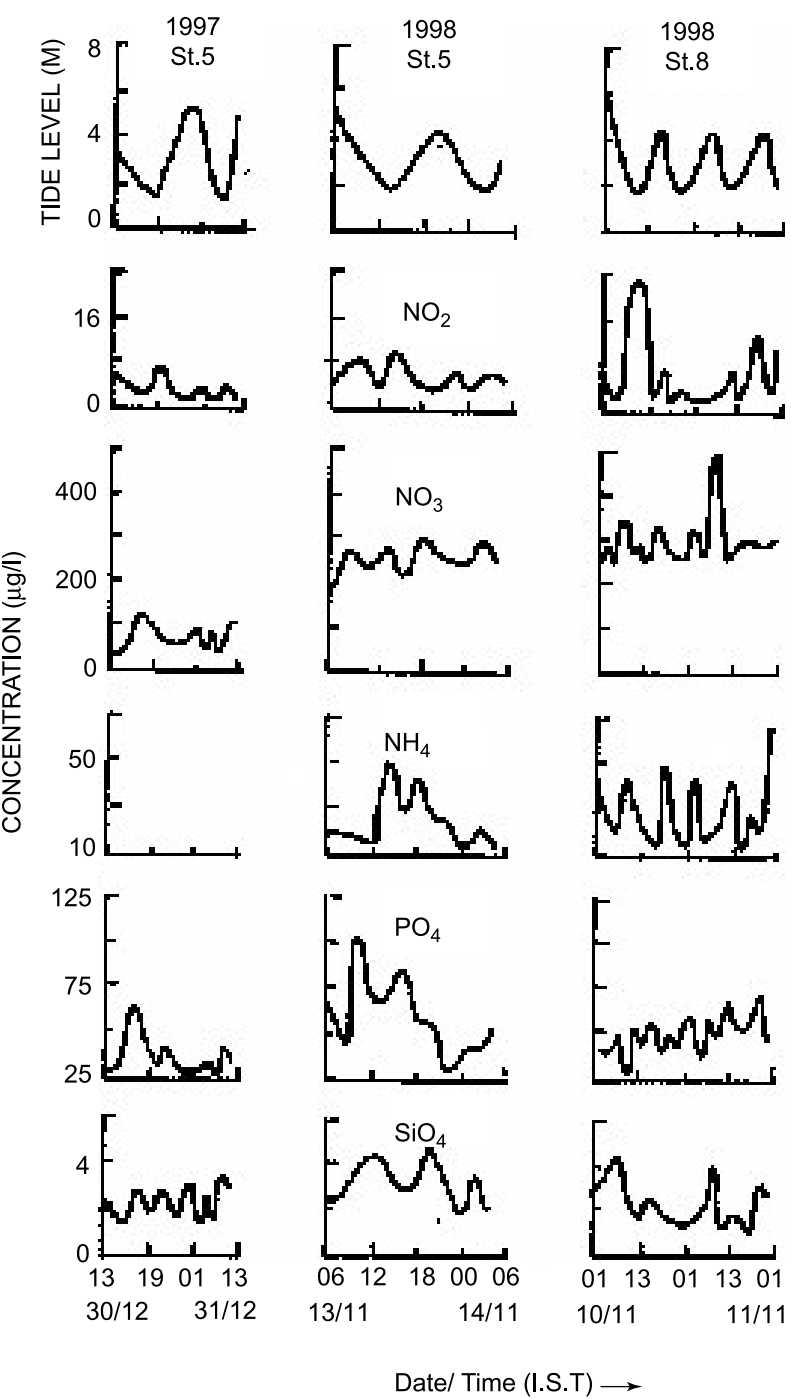

Figure 9. Tidal variation of hydro chemical characteristics at stations 5 and 8 during winter and post-monsoon seasons.

The estuarine environment is highly turbid and suspension of particles from sediments due to tidal and wave actions is very high. This was evident from high concentrations of total suspended matter (TSM) in surface waters during winter $(272$ to $782 \mathrm{mg} \mathrm{l}^{-1}$ ) summer (500 to $1036 \mathrm{mg} \mathrm{l}^{-1}$ ) and post-monsoon season (162 to $840 \mathrm{mg} \mathrm{l}^{-1}$ ), respectively in the study area. A similar trend was also recorded for the concentrations of TSM in the bottom water. These values are comparable with the estimated values from a model (figure 3; Sinha et al 2004) with a settling velocity $W s=8.8 \times 10^{-4} \mathrm{~m} \mathrm{~s}^{-1}$.

Nutrients $\left(\mathrm{NO}_{3}-\mathrm{N} ; \mathrm{NO}_{2}-\mathrm{N}: \mathrm{PO}_{4}-\mathrm{P}\right.$ and $\mathrm{SiO}_{4}{ }^{-}$ $\mathrm{Si}$ ) play a vital role owing to their variations in their concentrations from several inputs and biogeochemical processes (figure $8 \mathrm{a}$ and $\mathrm{b}$ ). The nitrogen compounds show distinct seasonal variations with highest concentrations during winter and post-monsoon seasons indicating the flow of

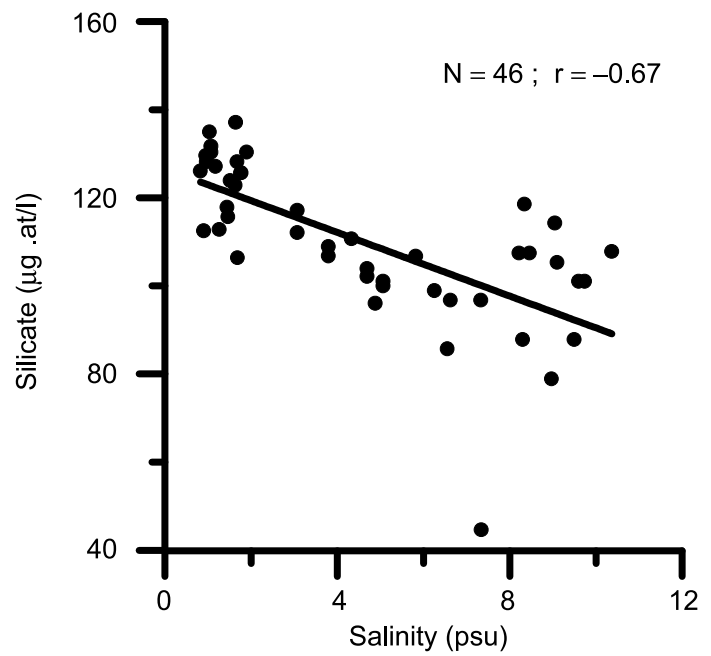

Figure 10. Relationship between salinity and silicate in the estuary.

local drain through fresh water run off while lowest concentrations are noticed in summer. Homogenous concentrations of nutrients in both surface and bottom waters showed that the estuary is well mixed and less stratified. High concentrations of nutrients noticed in the study region may be due to sewage from the adjacent township of Haldia refinery and industrial wastewater discharges from the upstream (Khan 1995) and also the addition of these nutrients in the catchment area. These values show the severe pollution load in the Hooghly estuarine system during recent times as evidenced from the total quantity of waste discharged (industrial and municipal) estimated as $1153.8 \mathrm{mld}$ reported by Ghosh (1973) and Khan (1995). The results indicated that all nutrients show seasonal variation and also that the impact of external sources were noticed in the study region (figure 8). In general, nutrient concentrations are low during summer compared to the other two seasons and the impact of pollutants load through run off is noticed during the post monsoon season compared to the dry season (summer). Further seasonal variation in these nutrients was attributed to the intake of nutrients by biota and the replenishment of nutrients under different seasons coinciding with blooms of diatoms reported during post-monsoon and early pre-monsoon (November to April) when nutrients were abundant (Santra and Pal 1989; De et al 1991a, 1991b) in the Hooghly estuary. Hence the involvement of these nutrients in biogeochemical cycles is evidenced from these seasonal variations.

Figure 9 depicts the tidal variation of nutrients in different seasons at stations 5 and 8 , which clearly indicate the impact of tide and fresh water during ebb tide in all the seasons. The scatter plot (figure 10) shows the non-linear relationship between salinity and silicate in the estuary during the 
Table 5. Phenols and PHC during winter, summer and post-monsoon seasons.

\begin{tabular}{|c|c|c|c|c|c|c|c|}
\hline \multirow[b]{2}{*}{ Station } & & \multicolumn{2}{|c|}{ Winter } & \multicolumn{2}{|c|}{ Summer } & \multicolumn{2}{|c|}{ Post-monsoon } \\
\hline & & $\begin{array}{l}\text { Phenols } \\
\left(\mu \mathrm{g} \mathrm{l}^{-1}\right)\end{array}$ & $\begin{array}{c}\mathrm{PHC} \\
\left(\mu \mathrm{g} \mathrm{l}^{-1}\right)\end{array}$ & $\begin{array}{l}\text { Phenols } \\
\left(\mu \mathrm{g} \mathrm{l}^{-1}\right)\end{array}$ & $\begin{array}{c}\mathrm{PHC} \\
\left(\mu \mathrm{g} \mathrm{l}^{-1}\right)\end{array}$ & $\begin{array}{l}\text { Phenols } \\
\left(\mu \mathrm{g} \mathrm{l}^{-1}\right)\end{array}$ & $\begin{array}{c}\mathrm{PHC}_{\left(\mu \mathrm{g} \mathrm{l}^{-1}\right)}\end{array}$ \\
\hline \multirow[t]{2}{*}{1} & $\mathrm{~S}$ & 63.8 & 89 & 18.4 & 15 & 12 & 07 \\
\hline & B & 39.2 & & 12.8 & 08 & 08 & 12 \\
\hline \multirow[t]{2}{*}{2} & $\mathrm{~S}$ & 38.9 & 42 & 22.4 & 20 & 09 & 11 \\
\hline & $\mathrm{B}$ & 31.2 & & 10.8 & 12 & 18 & 18 \\
\hline \multirow[t]{2}{*}{3} & $\mathrm{~S}$ & 25.7 & 23 & 15.8 & 18 & 06 & 18 \\
\hline & B & 22.0 & & 08.7 & 10 & 15 & 23 \\
\hline \multirow[t]{2}{*}{4} & $\mathrm{~S}$ & 15.6 & 80 & 18.4 & 12 & ND & 03 \\
\hline & B & 26.4 & & 07.4 & 11 & 12 & 12 \\
\hline \multirow[t]{2}{*}{5} & $\mathrm{~S}$ & 24.0 & 39 & 24.0 & 20 & 08 & 05 \\
\hline & B & 27.9 & & 14.2 & 08 & 13 & 18 \\
\hline \multirow[t]{2}{*}{6} & $\mathrm{~S}$ & 43.9 & 25 & 28.0 & 12 & 05 & 02 \\
\hline & B & 35.6 & & 15.0 & 06 & 08 & 12 \\
\hline \multirow[t]{2}{*}{7} & $\mathrm{~S}$ & 39.6 & 32 & 18.4 & 17 & 08 & ND \\
\hline & B & 31.5 & & 10.0 & 08 & 04 & 11 \\
\hline \multirow[t]{2}{*}{8} & $\mathrm{~S}$ & 28.6 & 42 & 21.2 & 18 & ND & ND \\
\hline & B & 37.4 & & 04.7 & 11 & ND & 07 \\
\hline
\end{tabular}

ND - nondetectable; S - surface; B - bottom.

period of our observations. The correlation coefficient is -0.67 (significant at $>99 \%$ level) which indicates the input of fresh water into this estuary. Silicate values resembling the salinity structure indicate that the aquatic environment under study is a typical tropical estuarine environment.

Petroleum hydrocarbons (PHC) in the present study varied between ND and $89 \mu \mathrm{g} \mathrm{l} \mathrm{l}^{-1}$ with highest concentrations during winter and lowest in summer. Similarly phenols ranged between ND and $63.8 \mu \mathrm{g} \mathrm{l}^{-1}$ (table 5). The concentrations of PHC and phenols in the study area are comparable with those reported earlier in estuaries of the west coast of India (Qasim 2003).

\section{Summary}

Physico-chemical characteristics of the Haldia channel of Hooghly estuary have been studied during winter, summer and post-monsoon seasons. Salinity at surface varied from $3.88-6.68$ psu under ebb tide conditions and 7.23-13.3 psu under flood tide conditions during summer. Salinity values are lower (0.17-1.11 psu and 1.63-2.60 psu under ebb and flood tidal conditions, respectively) during post-monsoon season.

Strong currents exceeding $100 \mathrm{~cm} \mathrm{~s}^{-1}$ were observed during peak ebb and flood tide conditions irrespective of the season. Longitudinal eddy diffusion coefficient $\left(K_{x}\right)$ was estimated as $757 \mathrm{~m} \mathrm{~s}^{-1}$ and $811 \mathrm{~m}^{2} \mathrm{~s}^{-1}$ during summer and post-monsoon seasons respectively. The vertical eddy diffusion coefficient $\left(\varepsilon_{v}\right)$ was estimated as $0.0337 \mathrm{~m}^{2} \mathrm{~s}^{-1}$ during post-monsoon season. In the study area, the reference density is suggested as 996.3 and
$996.6 \mathrm{~kg} \mathrm{~m}^{-3}$ for dry and low discharge conditions for modeling circulation in the estuary.

Values of $\mathrm{pH}, \mathrm{DO}$ and $\mathrm{BOD}$ are within the threshold limits of the estuarine environment. In spite of high concentrations of nutrients, seasonal variation of these parameters attributed to the biological intake and replenishment of nutrients coinciding with phytoplankton blooms showing their involvement in the biogeochemical cycle. High values $\left(160-2686 \mathrm{mg} \mathrm{l}^{-1}\right)$ of TSM were noticed both at the surface and bottom in the study region showing the impact of fresh water and sediment transportation.

\section{Acknowledgements}

The authors would like to thank Dr. E Desa, Former Director and Dr. S R Shetye, Director, N.I.O., Goa and Dr. K S R Murthy, Scientist-in-Charge, N.I.O., R.C., Visakhapatnam, for their encouragement and interest in this study. They would also like to thank Indian Oil Corporation Ltd., Haldia, for sponsoring the project. They are thankful to the anonymous reviewers for their valuable suggestions, which helped to improve the original version of the manuscript. This is NIO contribution no. 3925 .

\section{References}

Biswas A N 1985 Geohydro-morphometry of Hooghly estuary; J. Inst. Eng. (India) 66 61-73.

Chatterjee A K 1978 Two dimensional mathematical model of a tidal estuary; Proc. 47th Research session of CBIP, Hubli Dharwar, India. 
Chatterjee A K 1983 Two dimensional non linear vertically integrated model of a tidal estuary, River Behaviour and Control XV 1-11.

De T K, Ghosh S K, Jana T K and Chowdhary A 1991a Extinction coefficient and primary productivity in the mixing zone of Hooghly estuarine system; Indian Journal of Fisheries 37 199-209.

De T K, Ghosh S K, Jana T K and Chowdhary A 1991b Phytoplankton bloom in the Hooghly Estuary; Ind. J. Mar. Sci. 20 134-137.

Fischer H B, List E J, Robert C Y, Koh Imbuger J and Norme H B 1979 Mixing in inland and coastal waters; (London: Academic Press)

Ghosh B B, Ray P and Gopalakrishnan V 1973 Survey and characterization of waste water discharged into the Hooghly Estuary; J. Inland Fishery Soc. of India 4 2-10.

Gole G V and Vaidyaraman 1966 Salinity distribution and effect of fresh water flows in the river Hooghly; Proc. Tenth Congress of Coastal Engineering Tokyo 2 1412-1434.

Gole G V and Vaidyaraman 1969 Progressive salinity intrusion during the dry season in the Hooghly estuary; Int. Assoc. Hydrogr. Res Proc. Thirteenth Congress 3 275-282.

Grashoff 1976 Methods of sea water Analysis; (New York: weinheim, verlagchemie) 31149.

Joseph A and Desa E 1999 Evaluation of pressure transducers under turbid natural waters; J. Atmos. and Ocean. Tech. 16 1150-1155.

Joseph A, Desa E and Smith D 1997 Reduction in density of suspended sediment-laden natural waters; Second Indian National Conference on Harbour and Ocean Engineering (Inchoe, 97), Thiruvananthapuram, December 7-10, 1997.

Jyothi D, Ramana Murthy T V, Sarma V V and Rao D P 2000 Computation of diffusion coefficient for waters of Gauthami Godavari estuary using one dimensional advection diffusion model; Ind. J. Mar. Sci. 9 185-187.
Khan R A, 1995 The pollution problem of Hooghly estuarine system; Estuarine Ecosystem Series, Zoological survey of India, part 2, 497-542.

Mc Dowell D M and Prandle D 1972 Mathematical model for river Hooghly; J. Waterways and Harbour Division $A S C E \mathbf{9 8} 225-242$.

Qasim S Z 2003 Indian Estuaries (New Delhi: Allied Publishers).

Santra S C and Pal U C 1989 Phytoplankton of BhagirathiHooghly estuary. An illustrative account. Indian Biology 29 1-27

Schwind J J 1980 Geophysical Fluid Dynamics for Oceanography (England: Prentice Hall Inc.)

Shetye S R and Murthy C S 1987 Seasonal variation of the salinity in the Zuari Estuary; Proc. Ind. Acad. Sci. (Earth Planet. Sci.) 96 249-257.

Sinha P C, Rao Y R, Dube S K and Rao A D 1995 Modeling of circulation and salinity on Hooghly estuary; Mar. Geodesy. 19 197-213.

Sinha P C, Rao Y R, Dube S K and Rao A D 1996 Numerical Investigation of Tide Surge interaction in Hooghly estuary, India; Mar. Geodesy. 19 $235-255$

Sinha PC, Rao Y R, Dube S K and Murty C R 1998 A numerical model for residual circulation and pollutant transport in a tidal estuary (Hooghly) of NE Coast of India; Ind. J. Mar. Sci. 27 129-137.

Sinha P C, Rao Y R, Dube S K, Murty C R and Chatterjee A K 1999 Application of two turbulence closure schemes in the modeling of Tidal currents and salinity in the Hooghly estuary; Estuarine._Coastal Shelf Sci. 48 649-663.

Sinha P C, Guliani P, Jena G K, Rao A D, Dube S K, Chatterjee A K and Murty T 2004 A breadth averaged numerical model for suspended sediment transport in Hooghly estuary, East Coast of India; Natural Hazards 32 239-255. 